Vol. 9. Nomor 1, Tahun 2015

Fakultas Tarbiyah dan Ilmu Keguruan [FTIK]

IAIN Manado

\title{
PEMIKIRAN PENDIDIKAN ISLAM
}

Analisis Teologis-Normatif, Historis-Sosiologis dalam Filsafat Pendidikan Islam dan Implementasinya di Sekolah dan Madrasah

\section{Mustafa}

\begin{abstract}
ABSTRAK
Penelitian ini membahas tentang pemikiran pendidikan Islam yang telah tertuang dalam konsep ajaran Islam yang dilakukan penafsiran dan diimplementasikan berdasarkan pertimbangan kondisi atau konteks kekinian dengan pendekatanpendekatan yang ada. Permasalahan pokok yang dikaji terfokus pada teologisnormatif dan historis-sosiologis dalam konsep dan penyelenggaraan pendidikan Islam itu kemudian dilakukan analisis kembali yang berdasarkan orientasi pendidikan Islam dengan melahirkan paradigma dan gagasan-gagasan baru, sehingga dinamika pendidikan Islam itu berjalan sesuai dengan waktu untuk menghadapi tantangan zaman. Penelitian ini menggunakan pendekatan kefilsafatan untuk melihat konsep teologis-normatif dan historis-sosiologis pendidikan Islam dengan memakai pendekatan kualitatif dan analisis secara induktif dan deduktif. Hasil dari penelitian ini diantaranya adalah pemikiran pendidikan Islam dapat diimplementasikan di sekolah dan madrasah dengan gambaran mencoba lebih mengembangkan kearah yang lebih metodologis dan praksis, yang berangkat dari teori dan pemetaan pemikiran secara sosiologishistoris pendidikan dengan di reduksi kepada pengembangan yang lebih praksis sesuai dengan pengembangan di sekolah.
\end{abstract}

Kata Kunci: Pemikiran Pendidikan Islam, Teologis-Normatif, HistorisSosiologis, Sekolah, Madrasah.

\section{Pendahuluan}

Secara historis praktik penyelenggaraan pendidikan pada dasarnya seirima dengan pertumbuhan dan perkembangan masyarakat. dan sudah menjadi keyakinan umat Islam bahwa pendidikan Islam telah dimulai dari zaman nabi SAW. Rasulullah menyampaikan risalah kenabiannya untuk medidik masyarakat Arab dengan nilai-nilai ajaran Al-Quran yang pada awal pembinaannya sarat dengan pendidikan tauhid. Maka Awal dari pendidikan Islam itu sudah dimulai sejak Al-Quran diturunkan. Kemudian konsep pendidikan Islam itu mulai 
JURNAL PENDIDIKAN ISLAM IQRA'

Vol. 9. Nomor 1, Tahun 2015

Fakultas Tarbiyah dan Ilmu Keguruan [FTIK]

IAIN Manado

berkembang dan teraplikasi pada masa sahabat, tabi in, dan masa sesudahnya sampai sekarang.

Kasusnya di Indonesia fenomena program pendidikan Islam tersebut dimulai sebelum Indonesia merdeka sampai pendidikan itu berkembang hingga sekarang ini. Para ahli terjadi perdebatan terutama menyangkut ketokohan landasan filosofisnya. Disatu pihak ada yang menyatakan bahwa adanya kegiatan pendidikan Islam, Sistem pendidikan Islam yang memiliki ciri-ciri tertentu, menunjukkan adanya bangunan filosofis yang kokoh dari program dan praktik pendidikan Islam. Hal ini antara lain dikemukakan oleh Hasan Langgulung:

Tidak mungkin dibayangkan adanya pendidikan Islam, sistem pendidikan Islam yang mempunyai ciri-ciri, filsafat dan tujuan-tujuan yang mencerminkan ideologi kehidupan dalam masyarakat Islam tanpa adanya teori pendidikan Islam, atau pemikiran (filsafat) pendidikan Islam. ${ }^{1}$

Ma`arif setelah menyajikan dialog antara Iqbal dan Rumi dalam konteks pendidikan Islam, berkesimpulan bahwa fondasi filosofis yang mendasar dalam sistem pendidikan Islam selama ini masih rapuh, terutama Nampak pada adanya bentuk dualisme dikotomis antara apa yang diktegorikan ilmu-ilmu agama yang menduduki posisi fardhu ain, dan ilmu-ilmu sekuler yang paling tinggi berada pada posisi fardhu kifayah, yang seringkali terabaikan dan bahkan tercampakkan. Disamping itu kegiatan pendidikan yang seharusnya berorientasi ke langit (transcendental oriented), nampaknya belum tercermin secara tajam dan jelas dalam rumusan filsafat pendidikan Islam, dan bahkan belum dimilikinya. ${ }^{2}$ Karena itu penyusunan suatu filsafat pendidikan Islam merupakan tugas strategis dalam usaha pembaharuan pendidikan Islam.

Namun demikian, persoalannya adalah bagaimana corak tipe pemikiran mereka dalam membangun filsafat pendidikan Islam? Apakah konstruk pemikiran mereka dalam menyusun pemikiran tersebut dapat dipertanggungjawabkan secara

\footnotetext{
${ }^{1}$ Hasan Langgulung, Asas-asas Pendidikan Islam, (Jakarta: Al-Husna, 1987), h. 119.

${ }^{2}$ A. Syafii i Ma`arif, Peta Bumi Intelektualisme Islam di Indonesia, (Bandung: Mizan,
} 1993), h. 151. 
JURNAL PENDIDIKAN ISLAM IQRA'

Vol. 9. Nomor 1, Tahun 2015

Fakultas Tarbiyah dan Ilmu Keguruan [FTIK]

IAIN Manado

ilmiah-filosofis, ataukah hanya merupakan adopsi dari filsafat pendidikan barat untuk dicarikan legitimasinya dalam Islam, kemudian diberi label filsafat pendidikan Islam?

Merosotnya moral dan akhlak peserta didik disebabkan antara lain akibat kurikulum pendidikan agama terlampau padat pada materi dan materi tersebut lebih mengedepankan aspek pemikiran ketimbang membangun kesadaran keberagamaan yang utuh. Selain itu metodologi pendidikan agama kurang mendorong penjiwaan terhadap nilai-nilai keagamaan serta terbatasnya bahanbahan keagamaan. Buku-buku paket pendidikan agama belum memadai untuk membangun kesadaran beragama, memberikan keterampilan fungsional keagamaan dan mendorong perilaku bermoral dan berakhlak mulia pada peserta didik.

Dari uraian tersebut diatas dapat dipahami bahwa berbagai kritik dan sekaligus yang menjadi kelemahan bagi pendidikan agama lebih banyak bermuara pada aspek metodologi pembelajaran PAI dan orientasinya yang lebih bersifat normatif, teoritis dan kognitif, termasuk didalamnya aspek gurunya yang kurang mampu berinteraksi dengan mata pelajaran dan guru non pendidikan agama. Aspek lainnya yang banyak disoroti adalah menyangkut aspek muatan kurikulum atau materi pendidikan agama, sarana pendidikan agama termasuk di dalamnya buku-buku dan bahan-bahan ajar pendidikan agama.

Oleh karena itu dalam penelitian ini penulis akan mencoba mengkaji sejauh mana konsep teologis-normatif sebagai dasar pendidikan Islam dengan melihat pengalaman dalam praktek pendidikan Islam yang dikaitkan juga dengan kondisi historis-soiologis masyarakat yang mengitarinya yang kemudian dengan kata lain diperlukan kejelasan kerangka ontology, epistimologi, dan aksiologisnya. 
JURNAL PENDIDIKAN ISLAM IQRA'

Vol. 9. Nomor 1, Tahun 2015

Fakultas Tarbiyah dan Ilmu Keguruan [FTIK]

IAIN Manado

\section{Pembahasan}

\section{a. Iman dan Taqwa: Sebagai Asas Dalam Pendidikan Islam}

Iman dan taqwa sebenarnya sudah sering kita dengar dan ucapanucapanpada kegiatan-kegiatan sehari-hari, seperti pada khutbah jum'at, pembacaan Sapta Prasetyo Korpri, sumpah jabatan, dan sebagainya. Bahkan di dalam UU No. 02 Tahun 1989 tentang Sistem Pendidikan, dijelaskan bahwa "pendidikan nasional bertujuan mencerdaskan kehidupan bangsa dan mengembangkan Indonesia seutuhnya, yaitu manusia yang beriman kepada Tuhan Yang Maha Esa....,Kualitas adalah tingkat baik buruk sesuatu, atau mutu sesuatu. Mutu Indonesia yang dicita-citakan oleh bangsa Indonesia antara lain adalah manusia yang beriman' dan bertaqwa terhadap Tuhan Yang Maha Esa.

Pada dasarnya al-Qur'an secara gamblang telah mengemukakan dua kutubkualitas manusia, yaitu manusia yang ahsan taqwim, yakni kualitas terbaik, baikfisik maupun psikis; dan asfala safilin, yakni kualitas terendah (Q.S al-Tin: 5-6). Allah menciptakan manusia peluang untuk mencapai salah satu dari dua sisi tersebut! namun melalui tuntunanNya diketahui bahwa dia menghendaki agarsetiap pribadi manusia mencapai tingkat hasan taqwim, yakni manusia yang terbaik sesuai dengan asal kejadiannya, ia mencapai tingkat yang tertinggi dan keberuntungan dengan hidup yang kekal disisi Tuhannya, serta bahagia dan tidak menderita. ${ }^{3}$ Untuk meraihnya adalah dengaa senantiasa beriman dan beramal saleh.

Iman merupakan potensi rohani atau fitrah manusia, yang harus di aktualisasikan, dikembangkan dan di tingkatkan secara terus-menerus dengan cara melakukan amal saleh, sehingga dapat dicapai potensi rohani (iman) dalam bentuk taqwa. Prestasi iman (taqwa) ini juga perlu ditingkatkan secara terusmenerus sampai akhir hayat, baik melalui ta'allum atau melalui proses belajar mengajar, membaca buku-buku, menelaah tanda-tanda kebesaran Tuhan dan keagungannya di alam semesta penelitian dan eksperimen, diskusi seminar,

${ }^{3}$ Muhammad Husain al-Thabathaba'1, Al-Mizan Fi Tafsir al-Qur'an, (Beirut-Libanon: Muassasatr al-A,lami Li'Mathbu"at, 1983), h. 319. 
JURNAL PENDIDIKAN ISLAM IQRA'

Vol. 9. Nomor 1, Tahun 2015

Fakultas Tarbiyah dan Ilmu Keguruan [FTIK]

IAIN Manado

dialog, dan lain-lain, maupun melalui taqarrub atau upaya pendekatan diri kepada Tuhan dengan jalan ibadah, shalat, puasa, zikir, membaca dan memahami kandungan isi al-Qur'an dan sebagainya, karena derajat kemuliaan seseorang disisi Tuhannya justru di tentukan seberapa tinggi derajat taqwanya itu.

Dari hasil penelitian Mc Geoch di peroleh kesimpulan bahwa prestasi belajar pada orang dewasa naik lebih cepat untuk hal-hal ynag lebih abstrak" dan naik lambat untuk hal-hal yang bersifat konkrit. Ia juga memberikan kesimpulan bahwa semakin bertambah usia orang dewasa semakin luas, beragam dan tinggi kualitas prestasinya. Miles menyimpulkan dari hasil penelitiannya bahwa kualitas prestasi iman (taqwa) seseorang yang merupakan hal yang lebih abstrak, akan dapat semakin meningkat lebih cepat dan bahkan memiliki wawasan iman dan taqwa yang lebih luas dan mendalam kalau ia telah dewasa atau setidak-tidaknya.

Petunjuknya serta meningkat keahsan taqwim (kualitas manusia terbaik sesuai dengan kejadiannya), sebaliknya, jika nafsiyah manusia dalam hidup dan lebih tertarik pada dan dikuasai oleh kepentingan jismiyahnya' Sehingga yang diinginkan,diingat-ingat,dipikirkan,dirasakan, dan ditingkatkan hanya kenikmatan jismiyah belaka, maka kualitas prestasi iman (taqwa) akan semakin merosot,jatuh ke asfala safilin (kualitas terendah) bahkan lebih rendah dari pada binatang.

Bagaikan peserta didik yang sedang menempuh pendidikan disuatu Lembaga pendidikan, sebenarnya mereka telah memiliki potensi dan Kemampuan yang harus diaktualisasikan dalam kegiatan-kegiatan belajar' Tinggi rendahnya tingkat aktualisasi seseorang potensi terhadap potensinya itu akan sangat, menetukan terhadap kualitas prestasi yang mereka raih setelah lulus dari lembaga pendidikan itu, apakah Indeks Prestasinya cumlaude, sangat baik' baik atau sedang, dan seterusnya. Semuanya tergantung pada tingkatan aktualisasi mereka. Bilamana setelah tamat dari lembaga pendidikan tidak berusaha untuk belajar secara berkelanjutan atau berhenti dalam aktualisasi potensi dan kemampuannya, maka semakin dewasa akan semakin merosot dan menurun kualitas keilmuan dan keahliannya. Demikian pula dalam masalah iman dan 
JURNAL PENDIDIKAN ISLAM IQRA'

Vol. 9. Nomor 1, Tahun 2015

Fakultas Tarbiyah dan Ilmu Keguruan [FTIK]

IAIN Manado

taqwa. Apa hakikat iman itu? Apa pula hakikat taqwa? Dan bagaiman acara pengembangan iman dan taqwa tersebut? Pertanyaan-pertanyaan inilah yang di jawab dalam kajian ini.

\section{b. Iman dan Bertaqwa: Arah Pengembangan Pendidikan Islam}

Di dalam al-Quran dinyatakan bahwa, tujuan Tuhan menciptakan jin dan manusia adalah agar mereka menyembah kepadaNya (wamaa khalaqtu al-jinna wa al-insaliya,buduunil). Ibadah itu mencakup segala sesuatu yang dilakukan oleh manusia, baik berupa amal perbuatan, pemikiran atau perasaan' Yang senantiasa ditujukan diarahkankepada Allah nswt.TujuanTuhan menciptakan manusia ini kemudian di jadikan sebagai tujuaakhidari kegiatan pendidikan lslam.

Dalam Khazanah pemikiran pendidikan Islam, pada umumnya paru ulama berpendapat bahwa tujuan akhir pendidikan Islam adalah untuk beribadah kepada Allah swt, misalnya:

1. Dr. Muhammad Munir Mursyi, dalam bukunya "Al-Tarbiyohal- Islamiyah usshulu waTathawwaruha fi al- bilad al-arabiyahm" menyatakan: wa tuhdafu al-tarbiyah al-islamiyah ila tansyi'ah al- insyan al-ladzi ya' budullah wa yahsyaru' (pendidikan Islam itu diarahkan kepada peningkatan manusia yang menyembah kepada Allah dan takut kepadanya)

2. Dr. Ali Asyraf, dalam bukunya "New Horizon sin Muslim Education" menyatakan bahwa para sarjana muslim yang bertemu di Konferensi Dunia pertama tentang pendidikan Islam, mereka berpendapat bahwa: The ultimate aim of muslim education lies in the realization of complete submission to Allah on the level of the indivitlual, the community and humanity at large" (tujuan akhir dari pendidikan Islam terletak pada perwujudan dan penyerahan diri atau kefundukkan yang mutlak kepada Allah pada tangkat individu, masyarakat dan kemanusiaan pada umumnya). 
JURNAL PENDIDIKAN ISLAM IQRA'

Vol. 9. Nomor 1, Tahun 2015

Fakultas Tarbiyah dan Ilmu Keguruan [FTIK]

IAIN Manado

Di dalam UU No. 2 Tahun 1989 tentang Sistem Pendidikan Nasional dinyatakan, bahwa tujuan pendidikan Nasional adalah untuk mencerdaskan kehidupan bangsa dan mengembangkan manusia seutuhya'yaitu manusia yang beriman dan bertaqwa terhadap Tuhan Yang Maha Esa dan berbudi pekerti luhur, Memiliki pengetahuan dan ketrampilan ,kesehatan jasmani dan rohani, kepribadian yang mantap dan mandiri serta rasa tanggung iawab kemasyarakatan dan kebangsaan.

Kalau dalam sistem pendidikan nasional, pendidikan diarahkan untuk mengembangan manusia seutuhnya,yaitu manusia yang beriman dan bertaqwa, maka dalam konteks pendidikan lslam justru harus berusaha lebih dari itu. Dalam arti , pendidikan lslam bukan sekedar diarahkan untuk mengembangkan manusia yang beriman dan bertaqwa, tetapi justru berusaha mengembangkan manusia untukmenjadi imam/pemimpin bagi orang yang beriman dan bertaqwa (wajalna li al-muttaqina imaama). Di dalam sebuah hadits dinyatakan Kullukumraa inwakulluhlm mas'ulun'anraiyyatihi yakni masing-masing kamu adalah pemimpin (minimal pemimpin bagi dirimu sendiri)' dan masing-masing kamu akan diminta pertanggungiawaban atas kepimpinannya persoalan selanjutnya adalah: siapa sebenarnya imam/pemimpin bagi orang-orang yang bertaqwa itu? Dan upaya apa yang perlu dilakukan untuk menyiapkannya?

Untuk memahami profil imam/pemimpin bag iorang-orangy ang bertaqwa maka kita perlu mengkaji makna taqwa itu sendiri' Inti dari makna taqwa itu ada dua macam,yaitu itba,syariatillah(mengikuti ajaran Allah yang tertuang dan terkandung dalam al-Qur'an dan sunnah Rasulullah) dan sekaligus itba' sunnatillah (mengikuti aturan.aturan Allah yang berlaku dialam semesta ini).

Profil orang'orang yang itba'syari' atillah' adalah:

1. Mereka senatiasa membaca al-Qur'an dan al-sunnah' dan berusaha memahami ajaran Allah yang terkandung didalamnya, serta berusaha menghayatinya' 
JURNAL PENDIDIKAN ISLAM IQRA'

Vol. 9. Nomor 1, Tahun 2015

Fakultas Tarbiyah dan Ilmu Keguruan [FTIK]

IAIN Manado

2. Agar mereka dapat menghayatinya maka mereka harus memposisikan diri sebagai pelaku (actor) ajaran lslam, bukan hanya pemikir atau penalar, tetapi juga menjadi pelaku yang setia (loyal)' karena pada dasarnya agama Islam bukan sekedar intellectual exercise, tetapi jutru sebagai agama amal (action)'

3. Mereka memiliki komitrnen yang tinggin terhadap ajaran lslam;dan

4. Mereka siap berdedikasi dalam rangka menegakkan ajaran islam yang rahmatan li al" alamin'.

Karena itulah, profil orang.orang yangi rba'syori'atillah adalah mereka yang memiliki kemantapan aqidah, kedalaman spiritual, dan keunggulan moral (kesalehan individu dan kesalehan social), serta siap berjuang dan berdedikasi dalam menengakkan ajaran dan nilai.nila ilslam yang universal atau rahmatan li al-'alamin.

Disamping itu, orang yang bertaqwa juga sekaligus harus "itba'usunnatillah, (mengikuti aturan.aturan Allah yang berlaku di alam semesta). Profil orang-orang yang itba' sunnatillah' adalah:

1. Mereka berusaha membaca dan memahami fenomena alam (karena Dirinya merupakan bagian dari dan berada di alam),fenomena fisik dan Psikhis (karena dirinya sebagaimana makhluk individu),fenomena social (karena dirinya sebagai makhluk social),fenomena historis (karena dirinya dalam pentas sejarah)' dan fenomena yang lainnya'

2. Agar mereka dapat memahami sunnatullah' maka mereka harus memposisikan diri sebagai pengamat atau researcher(peneliti), Sehingga memiliki daya analisis yang tajam, kritis dan dinamis dalam memahami fenomena yang ada disekitarnya'

3. Mereka senatiasa membangun kepekaan intelektual serta epekaan informasi

4. Karena masing-masing orang mempunyai bakat' kemampuan' dan minat tertentu, maka dalam itba'usunnatillah perlu di sesuaikan dengan 
JURNAL PENDIDIKAN ISLAM IQRA'

Vol. 9. Nomor 1, Tahun 2015

Fakultas Tarbiyah dan Ilmu Keguruan [FTIK]

IAIN Manado

kemampuan dan keahlian masing-masing' sehingga terwuj udlah kematangan profesionalismenya'

Karena itulah, profil orang-orang yangi tba'sunnotillah adalah yang memiliki ketulusan wawasan dan keilmuan dan kematangan profesionalisme sesuai dengan bidang keahliannya'. Imam bagi orang yang bertaqwa berarti disamping disebagai orang yang memiliki profil sebagai orang yang itba'syari'atillah sekaligus itba' sunnatillah' juga mampu menjadi pemimpin, pengerak' pendorong innovator dan teladan bagi orang-orang Yang bertaqwa upaya apa yang perlu dilakukan untuk menyiapkan calon imam/pemimpin bagi orang-orang yang bertaqwa' maka harus dibangun dari atwai qurrota a'Wn (pasangan-pasangan yang menyenangkan hati)' atau pasangan-pasangan yang harmonis dan atau pasukan-pasukan kerja yang kompak' Dalam konteks pendidikan dapat dimaknai sebagai bangunan system pendidikan yang terdiri atas komponen-komponen yabg mempunayi hubungan harmonis dan terpadu'

Kekompakkan kerja dan keharmonisan hubungan diantara pasanganpasangan itu bukan berarti mengandung konotasi hubungan ketaatan danKepatuhan yang pasif,tetapi justru didalamnya terdapat hubungan yang dialogis dan bahkan dialektis. Namun demikian tetap dijaga dan dipelihara hubungan yang harmonis diantara pasangan-pasangan tersebut,yang diwujudkan dalam bentuk: 1. Adanya saling penegrtian'untuk tidak saling mendominasi;(2)adanya saling menerfuna, untuk tidak saling berjalan menurut kemauannya sendiri-sendiri;(3) adanya saling percaya' untuk tidak saling curigamencurigai;(4) saling menghargai, untuk tidak sating truth.claim(klaimkebenaran); d an(5)saling kasih sayang, untuk tidak saling membenci dan iri hati' agar kekompakkan kerja dan keharmonisan hubugan diantara pasangan. Pasanganitudapat terwujud, maka ada beberapa hal yang perlu dipertimbangkan dalam memilih dan menyeleksi pasangan atau mitra kerja dalam rangka membangun dan nmengembangkan sistem pendidikan lslam yaitu:

1. Istitha', yakni siap dan mampu untuk berpasangan secara harmonis; 
JURNAL PENDIDIKAN ISLAM IQRA'

Vol. 9. Nomor 1, Tahun 2015

Fakultas Tarbiyah dan Ilmu Keguruan [FTIK]

IAIN Manado

2. Lijamaliha (karena kecantikannya), dalam konteks pendidikan dapat bermakna profilnya yang menarik hati dari segi fisik maupun psikhisnya;

3. Limaliha (karena kekayaan harta/materinya) dalam konteks pendidikan dapat bermakna wawasan keilmuan dan keahliannya, atau kematangan profesionalismenya;

4. Linasabiha (karena keturunannya), dalam konteks pendidikan dapat bermakna asal usulnya atau latar belakang pendidikannyq siapa dia, dapat dipercaya atalu tidak; dan

5. Lidiniha (karena keagamaanya), dalam knteks pendidikan dapat bermakna perlunya seleksi komitmenya terhadap alarun Islam. atau kemantapan aqidah dan kedalaman spritualnya serta keunggulan moralnya.

Itulah antara lain beberapa hal yang perlu menjadi bahan renungan serta menjadi komitmen umat Islam terutama yang terlibat dalam usaha membangun dan mengembangkan sistem pendidikan Islam, guna menyiapkan generasi penerus yang qurrota a'yun dan calon-calon imam/ pemimpin bagi orang-orang yang beriman dan bertaqwa.

c. Jihad dan Tranformasi Sosial: Implikasinya Terhadap Guru Pendidikan Agama Islam.

Jihad dan Transformasi social seolah-olah merupakan dua sisi mata uang,yang secara konseptual dapat berdiri sendiri, tetapi dalam operasionalnya ternyata selalu ada kaitan yang tak terpisahkan. Proses transformasi sosial membutuhkan semangat jihad,dan jihad itu sendiri akan sia-sia bila tidak menelorkan produk, yang berupa transformasi sosial yang lebih baik sesuai dengan yang diedialkan. Dan lebih menarik lagi bila jihad dan transformasi sosial itu dikaitkan dengan tugas guru agama lslam, sebagai pendidikan agama lslam disekolah ataupun diluar sekolah, yang hendak mendidikkan ajaran dan nilai-nilai Islam kepada siswa atau masyarakat serta membimbing dan 
JURNAL PENDIDIKAN ISLAM IQRA'

Vol. 9. Nomor 1, Tahun 2015

Fakultas Tarbiyah dan Ilmu Keguruan [FTIK]

IAIN Manado

mengarahkan mereka agar memiliki komitmen terhada pelajaran lslam serta menjadikannya sebagai way of life.

Akhir-akhir ini ada semacam kritik yang ditujukan kepadapada guru agama,bahwa semangat kerja dan berjuang(jihad) dari para guru pendidik agama Islam nampaknya relatif menurun, jika dibandingkan dengan semangat dari para pendahulu mereka dalam mendidik dan mendakwahkan agama lslam. Turunnya semangat ini bisa jadi karena faktor global, yaitu menguatkannya faham meterialisme yang mendominasi kehidupan umat manusia yang mengahrapkan segala tindakan/perbatan atau kerja seseorang harus diperhitungkan dengan nilai materialnya atau untung dan ruginya secara material bila pandangan semacam ini berkembang dan membudaya dikalangan pendidikan agama lslam, maka bisa jadi ajaran jihad dalam lslam menjadi ide-ide kosong yang tak pernah membumi dan terwujud dalam realita.

\section{d. Reorientasi Paradigma Pengembangan Guru}

Guru dalam literatur dalam pendidikan Islam biasa disebut sebagai ustadz, mua`llim, murabbiy, mursyid, mudarris, dan mua addib. ${ }^{4}$ Namun di Indonesia yang paling familiar guru disapa dengan kata Ustadz. Ini mengandung makna bahwa seorang guru dituntut untuk komitmen terhadap profesionalisme dalam mengemban tugasnya. Seseorang dikatakan profesionalisme, bilamana pada dirinya melekat sikap dedikatif yang tinggi terhadap tugasnya, sikap komitmen terhadap mutu proses dan hasil kerja, serta sikap continous improvement, yakni selalu berusaha dan memperbaiki model-model atau cara kerjanya sesuai dengan tuntutan zamannya, ${ }^{5}$ yang dilandasi oleh kesadaran yang tinggi bahwa tugas mendidik adalah tugas menyiapkan generasi penerus yang akan hidup pada zamannya di masa depan.

\footnotetext{
1977).

4 Abd al-Fatah Jalal, Min al-Ushul al Tarbawiyah FI al-Islam, (Mesir: Dar al-Kutub,

5 Muhaimin, Paradigma Pendidikan Islam: Upaya Mengefektifkan Pendidikan Agama Islam di Sekolah, (Bandung: Remaja Rosadakarya, 2001).
} 
JURNAL PENDIDIKAN ISLAM IQRA'

Vol. 9. Nomor 1, Tahun 2015

Fakultas Tarbiyah dan Ilmu Keguruan [FTIK]

IAIN Manado

Dari telaah historis penelitian tentang efektifitas keberhasilan guru dalam menjalankan tugas kependidikannya, Medley menemukan beberapa asumsi keberhasilan guru, yang pada gilirannya dijadikan titik tolak dalam pengembangannya, yaitu: pertama, asumsi sukses guru tergantung pada kepribadiannya; kedua, asumsi sukses guru, tergantung pada frekuensi dan intensitas aktivitas interaktif guru dengan siswa; ketiga, asumsi bahwa apa pun dasar dan alasannya penampilan gurulah yang terpenting sebagai tanda memiliki wawasan, ada indikator penguasaan materi, ada indicator menguasai strategi belajar-mengajar dan lainnya. ${ }^{6}$

\section{Penutup}

1. Secara esensial ajaran dan nilai-nilai mendasar yang terkandung dalam alQuran dan al-Sunnah bercirikan universal dan abadi. Pemikiran Filsafat pendidikan Islam pada dasarnya dapat dilihat dari berbagai sudut pandang, yang mana masing-masing sudut pandang memiliki tipologi sendiri.

2. Secara epistimologik, akal budi manusia perlu ditumbuh-kembangkan secara berkelanjutan dalam proses pendidikan, baik melalui proses ta lim, tarbiyah, tadris, ta`dib dan irsyad maupun taqarrub yang bertolak dari pengembangan konsep tauhid uluhiyyah, rububiyah, mulkiyah, dan rahmaniyah, agar bersikap rasional-kritis, kreatif, mandiri, bebas dan terbuka, bersikap rasional empiric, objektif-matematis dan professional.

Berdasarkan kesimpulan diatas maka implikasi dari penelitian ini diharapkan:

1. Pemikiran pendidikan Islam hendaknya menjadi acuan dan pegangan bagi setiap individu dan khususnya pemikir dan praktisi pendidikan itu sendiri, agar mampu melihat dan memodifikasi sehingga bisa menginternalisasikan dan mengimplementasikan pendidikan secara kekinian dan yang akan datang.

${ }^{6}$ Noeng Muhadjir, Ilmu Pendidikan dan Perubahan Sosial Teori Pendidikan Pelaku Sosial Kreatif, (Yogyakarta: Tiara Wacana, 1994), hlm. 97. 
JURNAL PENDIDIKAN ISLAM IQRA'

Vol. 9. Nomor 1, Tahun 2015

Fakultas Tarbiyah dan IImu Keguruan [FTIK]

IAIN Manado

2. Corak dan strategi pemikiran yang berkembang adalah untuk dapat melihat pendidikan secara utuh dan sekaligus menjawab berbagai problema dan tantangan pendidikan kedepan khususnya dalam tubuh pendidikan Islam, sekaligus dapat memfilterisasi virus-virus dalam pendidikan sehingga pendidikan bisa formulasikan secara martabat dan berkualitas. 
JURNAL PENDIDIKAN ISLAM IQRA'

Vol. 9. Nomor 1, Tahun 2015

Fakultas Tarbiyah dan IImu Keguruan [FTIK]

IAIN Manado

\section{DAFTAR PUSTAKA}

Hasan Langgulung, Asas-asas Pendidikan Islam, Jakarta: Al-Husna, 1987.

Syafii`i Ma`arif, Peta Bumi Intelektualisme Islam di Indonesia, Bandung: Mizan, 1993.

Muhammad Husain al-Thabathaba'1, Al-Mizan Fi Tafsir al-Qur'an, BeirutLibanon: Muassasatr al-A,lami Li'Mathbu"at, 1983.

Abd al-Fatah Jalal, Min al-Ushul al Tarbawiyah FI al-Islam, (Mesir: Dar alKutub, 1977.

Muhaimin, Paradigma Pendidikan Islam: Upaya Mengefektifkan Pendidikan Agama Islam di Sekolah, (Bandung: Remaja Rosadakarya, 2001. 